Aleksandra Jovanović ${ }^{1}$

Filozofski fakultet, Doktorske studije

Univerzitet u Nišu

DOI 10.19090/ps.2020.2.204-207

\title{
PRIKAZ KNJIGE STATISTIČKI TESTOVI U PEDAGOŠKIM ISTRAŽIVANJIMA
}

\author{
(Jelena Maksimović i Jelena Osmanović, Statistički testovi u pedagoškim \\ istraživanjima, Filozofski fakultet Univerziteta u Nišu, Niš, 2020.)
}

Filozofski fakultet Univerziteta u Nišu 2020. godine izdao je udžbenik Statistički testovi u pedagoškim istraživanjima. Autorke ovog udžbenika su vanredna profesorka Jelena Maksimović i asistentkinja Jelena Osmanović na Filozofskom fakultetu Univerziteta u Nišu. Struktura udžbenika prati studijski predmet Statistika u pedagoškim istraživanjima koji se izučava na Departmanu za pedagogiju na Filozofskom fakultetu u Nišu. Udžbenik je namenjen studentima pedagogije, ali i ostalim studentima i istraživačima koji se bave istraživanjima vaspitno-obrazovne prakse. Nastao je kao rezultat rada na projektu „Pedagoški pluralizam kao osnova strategije obrazovanja“, broj 179036 (2011-2020). Recenzenti udžbenika su profesor emeritus Boris Kožuh, redovni profesor Veljko Banđur i vanredni profesor Zoran Stanković. Sastoji se od 195 stranica teksta sa slikovitim prikazima obrade podataka u programu SPSS (Statistical Package for Social Sciences). Autorke se opredeljuju za ovaj program kao osnovu statističke obrade podataka u pedagoškim istraživanjima, i svakom mladom istraživaču od izuzetnog je značaja da u svojim rukama ima ovaj udžbenik. Imanentnost ovog udžbenika ogleda se u razumljivom objašnjenju primene statističkih testova, odnosno u kojim prilikama je potrebno upotrebiti određene statističke testove i ono najvažnije, kako interpretirati statističke pokazatelje. Manipulisanje programom SPSS može biti zabavan posao ukoliko pred sobom imamo ovaj udžbenik koji nas korak po korak vodi ka uspešnoj obradi podataka i na kraju analizi i diskusiji rezultata istraživanja koje dobijemo. Autorke nas postepeno vode kroz osnove pedagoške statistike. Udžbenik se sastoji iz šesnaest tematskih celina, a na kraju udžbenika čitaoci mogu naći pojmovnik, indeks pojmova $i$ indeks autora kako bi lakše pronašli određene pojmove $i$ autore $u$ samom udžbeniku. Takođe, na kraju udžbenika mogu se upoznati sa kratkom biografijom autorki. Veoma koristan deo udžbenika jesu podsticaji na razmišljanje i aktivnosti u vidu pitanja i zadataka kojima se rezimira pročitano kao i preporučena literatura, a čitaoci ih mogu pronaći na kraju svake tematske celine.

1 aleksandra.s.jovanovic.88@gmail.com 
U prvom poglavlju Pojam i predmet pedagoške statistike autorke naglašavaju da studenti često izjednačavaju statistiku sa matematikom koja ih ne privlači tako često, međutim statistika podrazumeva logičko zaključivanje i može biti zanimljiva ukoliko otklonimo predrasude. Statističko znanje neophodno je svakom ko prati naučnu i stručnu literaturu, planira i realizuje istraživanja, obrađuje podatke i izvodi zaključke na osnovu koih će planirati dalje akcije i aktivnosti. Dobijeni rezultati putem programa SPSS moraju i mogu biti smislena celina ali je neophodno statističko znanje. Ukazuje se na etiku istraživača, kao i na valjanost istraživačkih instrumenata i statističkih postupaka za valjanost statističkih rezultata. Ovo poglavlje sadrži potpoglavlje Statistički metod u pedagoškim istraživanjima, gde autorke naglašavaju da je osnova testiranja određenih teorijskih znanja ili pretpostavki upravo statistički metod. Ističu se karakteristike pozitivističke paradigme, postpozitivizma, i pravi distinkcija između kvalitativnih i kvantitativnih istraživanja. Drugo poglavlje objašnjava osnovne pojmove, odnosno masovne pojave, statističke skupove, statističke serije i statističke podatke. Objašnjavajući masovne pojave ističu se pojave u vaspitanju i obrazovanju kojima se statistika može baviti kao što su učenici, škole, roditelji, nastavnici i ostalo, kao i da svaka masovna pojava ima statističku jedinicu. Treće poglavlje nosi naziv Merenje $i$ merne skale gde se objašnjava pojam merenja i opisuju karakteristike mernih skala, odnosno nominalne, ordinalne, intervalne i racionalne ili srazmerne merne skale. $\check{C}_{i}$ taoci mogu pročitati koja merna skala je najpodesnija za merenje određene pojave.

U četvrtom poglavlju Programski paket za statističku analizu podataka SPSS, čitaoci se uvode u statistički program SPSS koji se najviše koristi za obradu podataka u društvenim naukama. U potpoglavljima Priprema podataka za unos i Sređivanje, organizacija $i$ unos podataka detaljno se objašnjavaju početni koraci za rad u ovom programu. Nakon izrade projekta istraživanja, gde se definišu predmet, cilj, zadaci, hipoteze, varijable, metode, tehnike i instrumenti istraživanja, populacija i uzorak istraživanja, na kraju je potrebno definisati i statističku obradu podataka. Nakon realizacije istraživanja, istraživač kreira matricu, bazu podataka sa kojom kasnije manipuliše, odnosno obrađuje podatke u programu SPSS. Potrebno je varijablama dodeliti imena i operacionalizovati ih. Za svakog ispitanika je potrebno uneti vrednosti varijabli, koje će zavisiti od kategorije odgovora koje su već unapred isplanirane od strane istraživača. Matricu je potrebno sačuvati kako bismo uvek mogli da se vratimo obradi podataka. Izgledi matrice dati su slikovito kao i konkretna uputstva. U petom poglavlju, Program Descriptive Statistics (frekvencije, procenti), prelazi se na pokretanje određenih operacija u programu SPSS. Ukoliko se želi saznati koliko ispitanika se opredelilo za određeni odgovor na skali ili upitniku, potrebno je niz koraka u programu kako bi na kraju dobili tabelarni prikaz u Output-u. Šesto poglavlje Grafičko prikazivanje rezultata ukazuje na načine prikazivanja strukture podataka u vidu tabele ili grafikona, gde se ukazuje na načine grafičkog prikazivanja varijabli (Bar Charts, Pie Charts, Histogram). Sedmo poglavlje Ukrštanje varijabli (Crosstabs) objašnjava na koji način se varijable mogu ukrstiti, odnosno grupisati podaci prema varijablama. 
U osmom poglavlju Srednje vrednosti (aritmetička sredina, mod, modus, medijana) slikovito se objašnjava izračunavanje srednjih vrednosti kao i koju meru centralne tendencije koristiti. Slikovito se prikazuje zadavanje operacije izračunavanja srednjih vrednosti, kao i standardne devijacije koja prati aritmetičku sredinu, i minimalne i maksimalne vrednosti varijable.

Kako bi instument istraživanja bio pouzdan, odnosno relijabilan potrebno je testirati njegovu pouzdanost pomoću Kronbah Alfa testa, što se slikovito prikazuje u devetom poglavlju Pouzdanost instrumenata, gde se objašnjava kako se tumači rezultat ovog testa. Svaki instrument mora da bude validan, pouzdan, objektivan, diskriminativan. Deseto poglavlje Neparametrijski testovi posvećeno je objašnjenju suštine ove vrste testova, da im predstoji kreiranje hipoteze koja treba da se potvrdi ili odbaci. Njima se utvrđuje značajnost razlike, odnosno ovi testovi koriste se kod rezultata koji nisu normalno distribuirani, na malim uzorcima. Ekonomični su ali imaju manju pouzdanost od statističkih testova. Jedanaesto poglavlje posvećeno je hi-kvadrat testu koji se koristi za nominalne skale, gde se podaci pretvaraju u frekvencije i kojim se izračunava statistička značajnost razlika u odgovorima ispitanika. Slikovito se prikazuje kako se tumači ovaj test i statistička značajnost razlika. Dvanaesto poglavlje Parametrijski testovi kao i trinaesto poglavlje t-test $i$ F-test u pedagoškoj statistici objašnjavaju suštinu upotrebe parametrijskih testova u pedagoškoj statistici. Da bi se koristili parametrijski testovi potrebno je da rezultati budu normalno distribuirani ili približno normalno distribuirani, kao i da su rezultat merenja intervalnom ili omernom skalom. F-test, Fišerov test biramo kada imamo varijable sa više od dve kategorije i njime se utvrđuje statistička značajnost razlike varijanse, dok t-test koristimo kada imamo dve kategorije, odnosno dihotomnu varijablu, kojim se testiraju razike između aritmetičkih sredina. Slikoviti prikazi rada u SPSS-u i Output-i nas vode ka uspešnom radu u ovom programu i analizi ovih testova. Čitaoci će pročitati koje obrade treba da pokrenu u programu, kako tumačiti t-test na osnovu Levinovog testa (Levenes Test for Equality of Variances) i kako izračunati razlike unutar grupa ukoliko je F-test pokazao statističku značajnost razlika, odnosno da pokrenu neki post hok (Post Hoc) postupak, konkretno Bonferoni post hok postupak (Bonferroni Post Hock). Četrnaesto poglavlje posvećeno je merama korelacije, kojima se utvrđuje povezanost, odnosno uzročno-posledične veze među pojavama. Korelacije se izražavaju koeficijentom korelacije, mogu biti visoke, niske, pozitivne, negativne. Najčešće se koriste Pirsonov koeficijent korelacije i Spirmanov koeficijent rang korelacije. Treba biti obazriv u tumačenju povezanosti, a objašnjeni slikoviti prikazi u udžbeniku će čitaocu omogućiti da izbegne greške.

Kako je kreiranje instrumenata jedan od zadataka istraživača, petnaesto poglavlje Faktorska analiza je veoma korisno kako bismo naučili da odredimo broj faktora instrumenta koji smo konstruisali i kojim smo merili određene pojave, odnosno smanjimo broj varijabli, ekstrahujemo faktore, grupišemo ih u određeni faktor. Neophodno je utvrditi da li je faktorska analiza opravdana što se utvrđuje KMO-Kajzer Majer 
Olkin (Kaiser-Meyer-Olkin) testom i Bartletovim testom (Bartlet's test of sphericity). Istraživači se mogu opredeliti za Varimax i Promax rotaciju faktora. „Svaki faktor koji nosi preko 50\% ukupne kumulativne varijanse može biti faktor odabran za dalju statističku analizu“" (Maksimović i Osmanović, 2020: 145). Objašnjava se i način transformisanja, grupisanja varijabli u novu varijablu. U šesnaestom poglavlju dati su standardi za pisanje projekata istraživanja koji su neophodni svakom istraživaču. Ističe se IMRAD (Introduction, Method, Results, Analysis and Discussion) struktura pisanja rada. Na kraju su data zaključna razmatranja autorki kao i popis korišćene literature. Autorke između ostalog zaključuju „Naš udžbenik je imao za cilj da otkloni što više barijera u statističkoj obradi podataka i da pokaže koliko je digitalizacija u savremenoj školi olakšala put istraživačima za brzo i efikasno dobijanje željenih rezultata i saznanja“" (Maksimović i Osmanović, 2020: 171).

Danas je nezamislivo kreirati obrazovnu politiku bez oslanjanja na teoriju i na vaspitno-obrazovnu praksu, odnosno rezultate istraživanja vaspitno-obrazovne prakse. Udžbenik se preporučuje svima koji žele da realizuju svoje projekte istraživanja i da podatke koje dobiju statistički obrade na valjan način u programu SPSS. Slikoviti prikazi i objašnjenja kako tumačiti određene statističe testove omogućavaju istraživaču da valjano, bez greške interpertira svoje rezultate istraživanja. Autorke su dale veliki doprinos razvoju statističkog znanja kod studentske populacije, ali i svih koji se bave naukom i praksom, koji imaju statistička predznanja ali im je nedostajalo praktično znanje rada u programu SPSS. Ovaj udžbenik ima veliki naučni i praktični značaj i sigurno će doživeti više izdanja jer je izuzetno koristan. 